\title{
Anti-Trypanosoma cruzi Antibody Detection in Blood Donors in the Southern Brazil
}

\author{
Araújo A.B., Vianna E.E.S. and Berne M.E.A. \\ Parasitology Pos-graduation - Department of Microbiology and Parasitology, Federal University of Pelotas; Pelotas, RS, Brazil
}

\begin{abstract}
Trypanosoma cruzi, the causal agent of Chagas' Disease, is a widely spread protozoa in America. Blood transfusion is the secondly most important way of acquiring the infection. In blood banks, tests are performed to eliminate potentially infected blood. This study aimed to evaluate the positivity for $T$. cruzi in blood samples of donor's candidates in Southern Brazil. The study was based on a sampling containing all blood donors of Hemopel - a Pelotas City Blood Center, Rio Grande do Sul State, Brazil, from 2004 to 2005. Serological study was performed using ELISA Chagatest. Sampling containing values $\pm 20 \%$ cut off were evaluated using ELISA Chagatek, ELISA Alka/Adaltis, IHA Chagatest and IIF Imunocruzi. TESA-Blot was used as a confirmatory procedure in situations where blood samples showed conflicting results. From 4,482 samples collected in 2004 and 2005, the reactivity for anti-T. cruzi was $0.96 \%$ (43). Among those, 21 cases $(0.47 \%)$ were confirmed as positive - most of them were female, with low school level and averaging $47.2 \%$ years old. Interestingly, the blood donors are not aware of being contaminated and this fact makes it difficult for controlling the disease. Chagas' Disease was one of the main reasons for discarding blood bags through serological control in Southern Brazil. Sampling reactivity showed variation among the different techniques used for anti-T. cruzi research. In order to obtaining more secure and conclusive results, more than one diagnostic technique must be used.
\end{abstract}

Key-Words: Trypanosoma cruzi, blood donors, serological screening.

The blood transfusion became a significant way of Trypanosoma cruzi transmission with insect controlling systems, increased rural exodus and hemotherapy intensiveness, particularly in urban area.

The risks for transmission of Chagas' Disease through blood transfusion become evident when blood donators files are reviewed for infection with T. cruzi. A total of 1.09\% discharge of blood bags due to T. cruzi infection was observed in hemotherapy centers in Brazil [1]. In the Ribeirao Preto City Hemotherapy Regional Center (in Sao Paulo State), 1.1\% of all donators were positive for Chagas' Disease, from 1996 to 2001 [2]. Similar result was found in Rio de Janeiro City (1.17\%) [3]. Lower results were observed in Porto Alegre City, 0.32\% and 0.57\%, [4,5] and in São Paulo City Blood Center (0.14\%) [6]. Chagas' Disease prevalence was also observed in other American countries, such as Bolivia (14.79\%), Chile (1.2\%), Colombia (1.2\%), Equador (0.2\%), Nicaragua (0.24\%), Paraguay (4.5\%), Venezuela (1.32\%), Peru (1.32\%) [7], Mexico (1\%) [8] and the USA (Los Angeles, 1.1\%) [9].

Brazilian blood centers have been keeping a constant controlling of blood processing and quality. As a consequence, the levels of Chagas' Disease transmitted via blood contamination are decreasing [10]. Registers of blood transferring infection are still obtained though. Therefore, the knowledge of infection cases through blood transfusion and the chances for its occurrence justify the investigation of Chagas' Disease in blood centers. This paper aimed to study

Received on 15 June 2008; revised 28 October 2008.

Address for correspondence: Dr. Anelise Bergmann Araújo. E-mail: anelise_araujo@yahoo.com.br - Rua Benjamin Constant, 2009. Zip code: 96010-020. Pelotas, RS, Brazil.

The Brazilian Journal of Infectious Diseases

2008;12(6):480-482. (C) 2008 by The Brazilian Journal of Infectious Diseases and Contexto Publishing. All rights reserved. serum positivity for T. cruzi among blood donors in Southern Brazil, Rio Grande do Sul State.

\section{Material and Methods}

All blood donors of Pelotas City Blood Center (Hemopel), Rio Grande do Sul State, Brazil, from January 2004 to December 2005, composed the sampling. This institution receives blood from donors who live at cities on urban or rural areas of south of Rio Grande do Sul state. The donator candidates were physically evaluated and interviewed. In order to investigate the chances for T. cruzi infection, a standard set of questions, following the Brazilian legislation, was utilized. A routine serological searching for research of antibodies anti $T$. cruzi was conducted in Hemopel through ELISA (Enzyme Linked Immuno Sorbent Assay) test, using CHAGATEST ${ }^{\circledR}$ (Wiener lab, Argentina) kit which posses a specific methodology. Samples higher than the cut off point and within the lower $20 \%$ were repeated. In the cases where reactivity was permanent, a new sampling from the same donor was conducted and analyzed in duplicate using the same methodology. In order to classify the subject as positive or negative for Chagas' Disease, blood samples showing reactivity where processed using four other serological techniques, all of them containing specific methodology: ELISA CHAGATEK ${ }^{\circledR}$ (Biolab-Mérieux, Rio de Janeiro, Brazil), ELISA ALKA/Adaltis, IHA - Indirect Hemaglutination (CHAGATEST HAI ${ }^{\circledR}$ - Screening A-V - Wiener Lab, Argentina) and IIF - Indirect Immune Fluorescence (IMUNOCRUZI ${ }^{\circledR}$ - Biolab-Mérieux, Rio de Janeiro, Brazil). TESA-Blot [11] was performing in all samples with initially reactivity, used as a confirmatory method. All data set related to blood donors candidates and to positive donators for Chagas' Disease came from Hemopel profiles. To situate Chagas' Disease in the context of serological triage in Hemopel, discharge bags were studied through serological blockage in relation to other infectious agents. 


\section{Results}

Four thousand four hundred and eighty-two blood collecting were conducted in Hemopel during two years period, and $0.96 \%(43 / 4,482)$ where reactive for $T$. cruzi during the initial triage. In this period, Chagas' Disease was the second reason for blood bags discharging. The first reason was anti-HBc - antibodies against antigens of core of B hepatitis virus $(86 / 4,482 ; 1.92 \%)$ followed by anti-HCV antibodies against antigens of $\mathrm{C}$ hepatitis virus (38/4,482; $0.85 \%), \mathrm{HBsAg}$ - antigen of surface of B hepatitis virus (26/ 4,482; 0.58\%), syphilis (24/4,482; 0.54\%), anti-HTLV I/II antibodies against humane T-linfotropics virus (21/4,482; $0.47 \%$ ) and anti-HIV - antibodies against humane immune deficiency virus (14/4,482; 0.31\%).

TESA-blot, used as reference test for confirmation of $T$. cruzi infection, showed positivity in 21 samples, representing $0.47 \%(21 / 4,482)$ of all donations in Hemopel in 2004-2005. Samples considered positive through TESA-Blot test recognized bands of molecular weights of 150-160 kDa and $120-210 \mathrm{kDa}$

In relation to the final result, the analysis of intensity of optical density in samples obtained in the initial triage (ELISA Chagatest) showed that from 18 samples with low initial reactivity (DO < 0.5), 3 were positive and 15 were negative for T. cruzi; from 11 samples with intermediate initial reactivity (DO 0.5-1.5) only 5 confirmed positive; and from 14 samples with high reactivity $(\mathrm{DO}>1.5)$ only 1 was not positive (Figure 1 ).

Sampling reactivity was not uniform among the different techniques used. Of the 43 samples analyzed, 39.5\% presented co-positivity between all the techniques used. The agreement between the results of the reference test TESA-blot and others techniques presents the following results: ELISA Chagatest 49\% (22 false positives), ELISA Chagatek 95\% (1 false positive and 1 false negative), ELISA Adaltis 88\% (4 false positives and 1 false negative), IHA 95\% (2 false negatives) and IIF $88 \%$ ( 1 false positive and 4 false negatives).

Figure 1. Distribution of optical density $(450 \mathrm{~nm})$ from 43 samples reactive to ELISA-Chagatest, being 21 positive (closed) and 22 negative (open) by TESA-blot assay. The dotted line represents the cut off point of ELISA Chagatest.

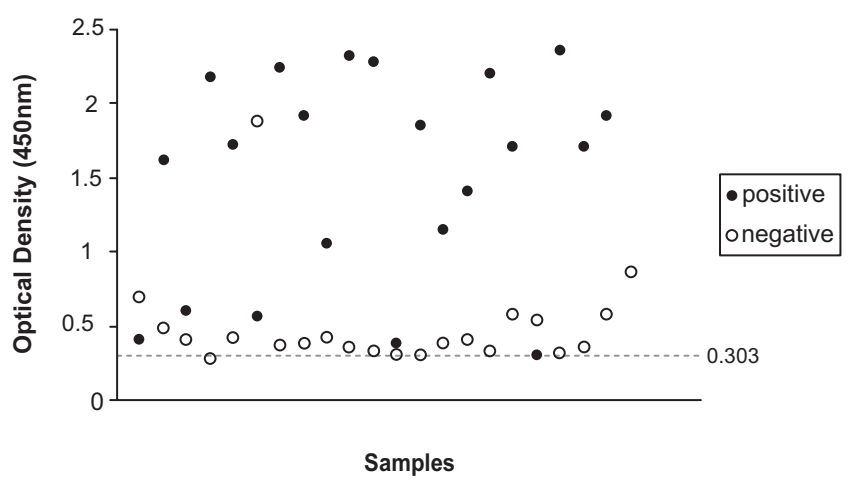

The profile of blood donators from Hemopel showed that $66 \%$ were male and $34 \%$ female. However, women presented the highest number (12/21) of positive cases for Chagas' Disease. The age varied between 20 and 60 years old, averaging 47.2. In terms of school level, 18 (86\%) were illiterate or have completed/ uncompleted elementary school and 3 (14\%) have completed/ uncompleted high school. About naturality, the majority was born in Canguçu (10/21), and the others in Pelotas (1/21), São Lourenço do Sul, (3/21), Santana da Boa Vista (2/21), Pinheiro Machado (2/ 21), São Francisco de Assis (1/21), Encruzilhada do Sul (1/21) e Piratini (1/21), all in southern of Rio Grande do Sul state.

According to Hemopel clinical reports of interview, no information obtained from the candidates allowed any relation to Chagas' Disease, showing that they are not aware of being contaminated.

\section{Discussion}

Chagas' Disease was the secondly reason for blood bag discharging in Hemopel during 2004-2005 period. However, in most of the hemotherapy centers, Chagas' Disease places an intermediate position $\left(3^{\text {rd }}, 4^{\text {th }}\right.$ or $\left.5^{\text {th }}\right)$ among the studied serologic parameters in blood centers. Anti-HBc is the most prevalent $[4,5,12,13]$.

Comparing the positivity for Chagas' Disease in blood donators at Brazil, our results (0.47\%) were similar to the ones observed in Bahia State, (0.35\%) [12] and superior to the ones found in Ribeirao Preto, Sao Paulo State, (0.14\%) [13]. Nevertheless, in blood donators of Nova Iguacu City, Rio de Janeiro State, and Londrina City, Parana State, the prevalence of T. cruzi infections was superior, 1.2 and $1.3 \%$, respectively $[3,14]$.

The number of discharged blood bags for reactivity for $T$. cruzi (43) was superior to the number of positive donators for Chagas' Disease (21). In routine observed in blood centers is increased the inferior gray zone, to have more sensitivity, but that elevates the number of false positive cases.

About the profile of positive individuals for Chagas' Disease, the average mean of positive donors observed in the present study was $47.2 \%$ years old, similar to the studies conducted on Brazil $[3,15,16]$, with cases observed in young individuals, and the origin of positive donors was coincident to the regions considered endemic [17]. The positive candidates showed a lack of knowledge of having been infected and that may difficult the control of Chagas‘ Disease.

Starting from the absorbance value obtained in initial reactivity in relation to the final result, absorbance values higher than the cut off suggest a positive result. The opposite is true with results close to cut off. The results obtained show this tendency. However, opposite situations also was found. Results with low absorbencies have been confirmed as positives, and negative results in a sample with a high optical density value have also been observed. It is important to consider special factors and situations, such as the beginning of an infection and the proper treatment, which ones could cause low readings, or crossing reactions and analytical contaminations, that may lead to increasing of absorbance values. 
The different results obtained among techniques were also described in the triage conducted in blood donators $[8,18]$. Those differences might be related to biological variables like lipemic, icteric or hemolised samples; crossing reactions or individuals undergoing treatment. The extract quality and purity, cepa origin and parasite form used in antigen preparation may also be able to interfere with the final results [19-24]. Additionally, antigen fixation in plate, conjugate concentration and quality, and other reactives must be considered. During the execution process, other variables such as reagent quality and preparation, washing and possible contaminations can also affect the final results.

Antigenic variability observed among T. cruzi cepas gives strength to the preoccupation with quality of serological triage for Chagas' Disease. If one does not take into account cost, reorganization of blood center routine and preoccupation with other infectious agents, many studies defend the use of more than one technique for a safe serological triage in blood centers [18,25-28].

In conclusion, there are positive individuals for $T$. cruzi among blood donators of Hemopel and they do not know about the infection. There are also discussing issues and false negatives results between the used techniques on the serological triage of blood donors. Therefore, more than one diagnostic technique must be applied for a conclusive and safe result, especially on endemic regions.

\section{Acknowledgements}

Our thanks to Dr. Eufrozina S. Umezawa, from the Institute of Tropical Medicine of São Paulo, for providing the TESABlot used in this study, and Dr. Eduardo Xavier, from Federal University of Pelotas, RS, for the English review.

\section{References}

1. Wendel S., Shikanai Yasuda M.A., Silva G.R. Spatial statistics analysis from rejected blood units for Chagas disease in Brazil: Application of spatial continuous analysis and geostatistical tools. Rev Bras Hematol Hemoter 2004;26(supl.2):282.

2. Soussumi L.M.T., Covas D.T., Passos A.D.C. Positividade para a Doença de Chagas entre doadores de sangue do Hemocentro de Ribeirão Preto. Rev Bras Hematol Hemoter 2004;26(supl.2): 280.

3. Silveira H.J., Mozart O.N., Norberg A.N., et al. Trypanosoma cruzi prevalence and clinical forms in blood donor candidates in Brasil. Rev Saúde Pública 2003;37:807-9.

4. Capra M.S., Souza S.R., Santos A.P., et al. Características das doações realizadas no Serviço de Hemoterapia do Complexo Hospitalar Santa Casa de Porto Alegre/RS. Rev Bras Hematol Hemoter 2005;27(supl.2):259.

5. Juckowsky C.A., Pires M.C., Flores M.E.C., et al. Impacto do voto de auto-exclusão confidencial na triagem sorológica dos doadores de sangue no Serviço de Hemoterapia do HCPA-RS. Rev Bras Hematol Hemoter 2005;27(supl.2):266.

6. Salles N.A., Sabino E.C., Barreto C.C., et al. Descarte de bolsas de sangue e prevalência de doenças infecciosas em doadores de sangue da Fundação Pró-Sangue/Hemocentro de São Paulo. Rev Panam Salud Publica 2003;13:111-5.

7. Schmunis G.A., Zicker F., Pinheiro F., et al. Risk for TransfusionTransmitted Infectious Diseases in Central and South America. Emerg Infect Dis 1998;4:5-11.

8. Bracho C.G., García L.G., Verdugo J.F., et al. Riesgo de transmisión de Trypanosoma cruzi por transfusión de sangre en México. Rev Panam Salud Publica 1998;4:94-9.
9. Kerndt P.R., Waskin H.A., Kirchoff L.V., et al. Prevalence of antibody to Trypanosoma cruzi among blood donors in Los Angeles, Califórnia, Brazil. Transfusion 1991;31:814-8.

10. Manual Técnico para Investigação da Transmissão de Doença de Chagas no Sangue. 1 ed 2 reimp. Brasília: Agência Nacional de Vigilância Sanitária/ Ministério da Saúde/ Brasil 2005.

11. Umezawa E.S., Nascimento M.S., Kesper Jr. N., et al. Immunoblot Assay Using Excreted-Secreted Antigens of Trypanosoma cruzi in Serodiagnosis of Congenital, Acute and Chronic Chagas' Disease. J Clin Microbiol 1996;34:2143-7.

12. Figueiredo V.M., Romeo M., Circuncisão D.A., et al. Positividade dos marcadores sorológicos da Fundação Hemoba. Rev Bras Hematol Hemoter 2005;27:333.

13. Valente V.B., De Biase R.R. Ângulo I.L., et al. Estudo da reatividade dos marcadores sorológicos em doadores e doações no Hemocentro de Ribeirão Preto - 2004. Rev Bras Hematol Hemoter 2005;27:331.

14. Bonametti A.M., Castelo $\mathrm{F}^{\circ}$ A., Ramos L.R., et al. Soroprevalence of Trypanosoma cruzi infection in students at the seven-fourteen age range, Londrina, PR, Brazil, in 1995. Mem Inst Oswaldo Cruz 1998;93:727-32.

15. Onsten T.G.H., Dutra I, Marafon J., et al. Análise de uma população de doadores com sorologia reagente: idade significativamente mais alta nos doadores com marcadores para Chagas e Lues comparados com doadores reagentes para vírus. Rev Bras Hematol Hemoter 2005;27:325.

16. Santos R.M., Costa R.O., D’Avila F.S., et al. Perfil dos doadores com sorologia não reativa para anti-HIV, anti-HTLV, D. Chagas e Sífilis, atendidos no Hemonúcleo de Santos. Rev Bras Hematol Hemoter 2005;27:332.

17. Baruffa G., Alcântara $\mathrm{F}^{\circ} \mathrm{A}$. Inquérito sorológico e entomológico da infecção pelo T. cruzi na região sul do Rio Grande do Sul. Ann Soc Belge Med Trop 1985;65:171-9.

18. Sanchéz-Guillén M.C., Barnabé C., Juegan J.F., et al. High prevalence anti-Trypanosoma cruzi antibodies, among blood donors in the state of Puebla, a non endemic area of Mexico. Mem Inst Oswaldo Cruz 2002;97:947-52.

19. Morel C., Chiari E., Camargo E.P., et al. Strains and clones of Trypanosoma cruzi can be characterized by pattern of restriction endonuclease products of kinetoplast DNA minicircles. Proc Natl Acad Sci USA 1980;77:6810-4.

20. Carneiro M., Romanha A.J., Chiari E. Biological characterization of Trypanosoma cruzi strains from different zymodemes and schizodemes. Mem Inst Oswaldo Cruz 1991;86:387-93.

21. Souto R.P., Fernandes O., Macedo A.M., et al. DNA markers define two major phylogenetic lineages of Trypanosoma cruzi. Mol Biochem Parasitol 1996;83:141-52.

22. Fernandes C.D., Murta S.M.F., Cerávolo I.P., et al. Characterization of Trypanosoma cruzi strains isolated from Chronic Chagasic Patients, Triatomines and Opossums Naturally Infected from the State of Rio Grande do Sul, Brazil. Mem Inst Oswaldo Cruz 1997;92:343-51.

23. Ruiz-Garcia M., Montilla M., Nicholls S.O., et al. Genetic relationships and spatial genetic structure among clonal stocks of Trypanosoma cruzi in Colombia. Heredity 2000;85:318-27.

24. Añez N., Crisante G., Silva F.M. da, et al. Predominance of lineage I among Trypanosoma cruzi isolates from Venezuelan patients with different clinical profiles of acute Chagas' disease. Trop Med Int Health 2004;9:1319-26.

25. Salles N.A., Sabino E.C., Cliquet M.G., et al. Risk of exposure to Chagas' disease among seroreactive Brazilian blood donors. Transfusion 1996;36:969-73.

26. Saez-Alquézar A., Sabino E.C., Salles N., et al. Serological Confirmation of Chagas' Disease by a Recombinant and Peptide Antigen Line Immunoassay: INNO-LIA Chagas. J Clinical Microbiol 2000;38:851-4.

27. Sobreira A.C.M., Gomes F.V.B.A.F., Silva M.A.M., et al. Prevalência de infecção chagásica em doadores de sangue do Hemocentro Regional de Iguatu, CE. Rev Soc Bras Med Trop 2001;34:193-6.

28. Gutierrez R., Angulo V.M., Tarazona Z., et al. Comparison of four serological tests for the diagnosis of Chagas disease in a Colombian endemic area. Parasitology 2004;129:439-44. 